\title{
W kręgu opracowań fundamentalnych
}

\author{
Leszek Małczak, Croatica. Literatura i kultura chorwacka \\ w Polsce w latach 1944-1989, Wydawnictwo Uniwersytetu \\ Śląskiego, Katowice 2013, 872 s.
}

Leszek Małczak znany jest w polskiej i międzynarodowej przestrzeni slawistycznej jako autor m.in. wartościowej i interesującej monografii Wiatr w literaturze chorwackiej. O figurze literackiej wiatru w XIX- $i X X$ -wiecznym piśmiennictwie chorwackim strefy śródziemnomorskiej (Poznań, Wydawnictwo Naukowe UAM, 2004). Publikacja ta wiąże idee tematu i utożsamienia, fenomeny niepowtarzalne i indywidualne, których byt istnieje poza rzeczywistością historyczną, a przy tym rzuca światło na ważny aspekt chorwackiego paradygmatu kulturowego. Na tym tle zaskakująca i nieoczekiwana wydaje się radykalna zmiana zainteresowań naukowych Leszka Małczaka, które reprezentuje omawiana publikacja: opracowanie idiograficzne i źródłowe z zakresu badań fundamentalnych i interdyscyplinarnych, rekonstruujące polityczne, ideologiczne i historyczne czynniki szeroko rozumianej krytyki recepcji i przekładu.

Określenie zakresu przedmiotowego tego dzieła jednym i adekwatnym terminem, sytuującym je w obrębie krytyki przekładu, współpracy kulturalnej, socjologii produkcji literackiej (Żółkiewski) bądź polsko-chorwackich i chorwacko-polskich kontaktów międzyliterackich nie jest możliwe, gdyż obejmuje ono bardzo szeroki zakres przedmiotowy wymienionych pól badawczych. Opracowanie Leszka Małczaka składa się z dwóch części, wyróżnionych wizualnie kolorami papieru, tj. z opracowania odautorskiego i bibliografii. Należy podkreślić, że w odniesieniu do żadnego innego słowiańskiego kraju nie istnieje podobne opracowanie, którego ambicją byłaby rekonstrukcja tak rozległego zakresu źródeł oraz mechanizmów i regulacji formalnych obecności literackiej oraz kulturalnej w Polsce. 
Zanim przejdziemy do oceny realizacji szeroko zakrojonego i niezwykle ambitnego przedsięwzięcia, warto pochylić się nad deklaracjami badawczymi autora. Pisze on w uwagach wstępnych: „W niniejszej książce nie tylko rekonstruuję dane faktograficzne i tworzę bazę informacji na temat związków kulturalnych pomiędzy Polską i Chorwacją, lecz także staram się odkryć i opisać reguły budowania współpracy kulturalnej pomiędzy obydwoma narodami, pokazać jej mechanizmy, zanalizować środki i sposoby komunikacji międzyliterackiej i międzykulturowej” (s. 9). Powyższe deklaracje wskazują na rzeczywisty obszar zainteresowania naukowego wysiłku Leszka Małczaka, który skierowany jest na źródłowy, zewnętrzny wobec autonomii dzieła literackiego i recepcyjny aspekt komunikacji międzyliterackiej. Nie oznacza to, że autor ograniczył własne pole badawcze; wręcz przeciwnie: oprócz literatury Leszek Małczak ogląda realia i mechanizmy współpracy kulturalnej w sferze filmu, muzyki, teatru i sztuk plastycznych, przy czym i te przykłady nie wyczerpują zakresu i charakteru recenzowanego dzieła.

Kluczowa pozostaje kwestia zrozumienia istoty głównego przedsięwzięcia badawczego monografii Croatica. Literatura i kultura chorwacka w Polsce w latach 1944-1989. Autor wykonał monumentalne zadanie, gromadząc materiały z dostępnych bibliografii oraz licznych czasopism i wydawnictw ciągłych - wymieńmy dla przykładu polskie: „Almanach Sceny Polskiej”, „Dialog”, „Literatura na Świecie”, „Mały Rocznik Filmowy”, „Nowe Książki”, ,Pamiętnik Słowiański”, „Poezja”, „Rocznik Literacki”, „Ruch Wydawniczy w Liczbach”, „Twórczość”, „Życie Literackie”, „Ruch Muzyczny”, „Życie Słowiańskie”, „Odra”, „Współczesność”, „Teatr” oraz jugosłowiańskie / chorwackie: „Kulturni život”, „Bilten Saveznog zavoda za međunarodnu naučnu, prosvetno-kulturnu i tehničku saradnju” „Književna smotra”, „Most”. Materiał ten uzupełniają konwencje, plany i programy współpracy, raporty ambasad, protokoły posiedzeń komisji (Archiwum Ministerstwa Spraw Zagranicznych RP, Archiwum Ministerstwa Kultury i Dziedzictwa Narodowego, Archiwum Akt Nowych w Warszawie, Archiwum Jugosławii, Chorwackie Archiwum Państwowe), programy festiwali, katalogi wystaw i inne.

Ten imponujący zakres źródeł, bez precedensu we współczesnej slawistyce (jeśli brać pod uwagę dzieła pojedynczych badaczy), budzi szczery podziw i wielki szacunek. Opracowana przez autora bibliografia 
w syntetyczny i uporządkowany sposób daje wgląd w olbrzymi materiał, ale jednocześnie uświadamia ogrom zrealizowanego zadania.

Opracowanie Leszka Małczaka mieści w jednym wolumenie dwie odrębne, chociaż powiązane ze sobą części: pierwsza ma charakter opracowania merytorycznego, druga zawiera bibliografię (dokumentację) chorwacko-polskich kontaktów kulturalnych. Otwierające pierwszą część rozdziały tworzą tekst o charakterze wstępnym i kontekstowym. W rozdziale Ogniwa pośredniczace (s. 27-60), w czterech rozbudowanych podrozdziałach (poniżej omawiam je bardziej szczegółowo), autor kreśli fundamentalną dla tego typu przedsięwzięć perspektywę socjologii literatury oraz badań z zakresu komunikacji międzykulturowej, literackiej i międzyliterackiej, eksponuje instytucję literatury przekładowej i kładzie nacisk na rolę ogniw pośredniczących (tłumacze oraz ich organizacje, wydawnictwa, czasopisma, krytyka przekładu) między kulturą źródłową (chorwacką) a docelową (polską) zarówno w doborze dzieł, jak i lokowaniu obcej kultury w nowym kontekście kulturowym, społecznym i politycznym. Badacz eksponuje płaszczyznę ideologiczną oraz rolę struktur władzy w ogóle, w tym znaczenie polityki przekładowej, kulturalnej, wydawniczej, która - co było typowe dla rzeczywistości państw „realnego socjalizmu" - podlegała całkowitej kontroli reprezentantów struktur etatystycznego państwa (Jugosławia) i państwa autorytarnego (Polska), o ile pominiemy ewolucję struktur państwowych Polski od totalitaryzmu typu stalinowskiego do Gierkowskiej modernizacji i Polski stanu wojennego. Rozdział ten odwołuje się do fundamentalnych dzieł z zakresu przekładu, socjologii literatury i życia literackiego, cytowani są np. Dioniz Durišin, André Lefevere, Susan Bassnett, Anna Legeżyńska, Bożena Tokarz, Stefan Żółkiewski, Leo Löwenthal, Viktor Žmegač, Aleksandar Stipčević, Janusz Sławiński, Hans Norbert Fügen, Robert Escarpit, Raymond Williams, Edward Balcerzan i inni. Jednak trzeba powiedzieć jasno, że powyższe credo metodologiczne nie stało się podstawą procesu badawczego prezentowanego w publikacji.

Rozdział drugi (Polityka kulturalna Jugosławii i Polski, współpraca kulturalna oraz jej ramy prawne) prezentuje kontekst polityczno-prawny współpracy. W odrębnych podrozdziałach syntetycznie omówiony jest całokształt kontaktów kulturalnych w okresie lat 1944-1989, polityka kulturalna PRL i polityka Jugosławii, przy czym poznajemy chorwackie 
i serbskie oblicze polityki jugosłowiańskiej, uzyskując (powierzchowny) wgląd w specyfikę różnic kulturowych tego federacyjnego państwa.

W tym miejscu powinniśmy przejść do kwestii bardziej zasadniczej, a mianowicie zwrócić uwagę na perspektywę badawczą. Autor tropi i dokumentuje ślady, które na kontaktach kulturalnych Polski z zagranicą pozostawiały relacje jugosłowiańsko-radzieckie oraz reformy ustrojowe w Jugosławii i sferę instytucjonalnych organów państwowych. W efekcie monograficzne opracowanie Leszka Małczaka szczegółowo rekonstruuje przestrzeń, która rozpościera się pomiędzy źródłowym dziełem literackim (artystycznym) a instytucjami i organami państwa, kształtującymi politykę i „wymianę kulturalną”. Autor w niewielkim stopniu referuje recepcję tej twórczości, omawiając recenzje i omówienia, które często powstawały pod piórem osób podporządkowanych oficjalnej wykładni polityki kulturalnej. Leszek Małczak relacjonuje, wskazuje i dokumentuje czynniki współkształtujące sferę kontaktów: elementy kontroli i sterowania, manipulację, cenzurę i autocenzurę, instytucjonalny aspekt polityki kulturalnej oraz szczeble kontroli (KC PZPR, KPJ [Komunistyczna Partia Jugosławii], Ministerstwa Kultury i Sztuki) Polski i Jugosławii, uzależnienie polityki kulturalnej PRL od polityki ZSRR, izolację, zamknięte granice.

Pięć kolejnych rozdziałów, od trzeciego do siódmego: $W$ cieniu agitpropu (1944-1948); Bomba jugosłowiańska (1949-1955); Normalizacja (1956-1962); Ku decentralizacji i kulturom narodowym (1963-1973); Coraz mniej Jugosławii, coraz więcej Chorwacji (1974-1989) przejmuje porządek chronologiczny, problemowy i tematyczny ze sfery zewnętrznych uwarunkowań współpracy międzyliterackiej, wymiany kulturalnej i życia literackiego. Oznacza to, że ważnymi elementami postępowania badawczego, tworzącego konstrukcyjną i kompozycyjną oś wątku odautorskiego, są przełomowe daty w historii Jugosławii oraz Polski, a heurystyka wywodu potwierdza tezę, że całokształt życia kulturalnego i międzypaństwowych relacji w tym zakresie podporządkowany był rzeczywistości politycznej. Użyte sformułowania mogą niesprawiedliwie i nietrafnie przywodzić na myśl anachroniczne inspiracje rodem z dziewiętnastowiecznego idiografizmu. Byłaby to jednak diagnoza krzywdząca. Leszek Małczak, w oczywisty sposób rekonstruując obraz polsko-jugosłowiańskiej współpracy kulturalnej, dostrzega i konstatuje zależność sfery kultury od wewnętrznego kontekstu politycznego w obu krajach, wzajemnych kontaktów, a także 
sytuacji międzynarodowej. Istotą opracowania nie jest jednak hermeneutyczna interpretacja określonego porządku problemowego; rezultat badań wykracza poza kompleks problemowy polsko-chorwackiej współpracy międzykulturowej, ukazując rzeczywisty, społeczny i kulturowy charakter epoki.

Opracowanie Leszka Małczaka ma fundamentalne znaczenie pod względem poznawczym i naukowym, lokując się jako kompendium wiedzy źródłowej z zakresu relacji kulturowych polsko-jugosłowiańskich, szczególnie polsko-chorwackich, jawiąc się jako swego rodzaju panorama o charakterze historyczno-kulturowym, obejmująca swoim zakresem: 1) źródłowo - literaturę, film, teatr, malarstwo, muzykę, a w szczególności przekładoznawstwo; 2) kontekstowo - działalność instytucjonalną stowarzyszeń literackich, politycznych i administracyjnych, rządowe i międzynarodowe akty normatywne, czasopiśmiennictwo, praktykę życia literackiego i wiele innych. Cezury historyczne opracowania stanowią nadrzędną ramę periodyzacyjną i konceptualizacyjną; autor omawia zjawiska w podziale na okresy, wyznaczane przez ważne wydarzenia historyczne, polityczne i społeczne. Porządek ten ilustrują tytuły rozdziałów: W cieniu agitpropu (1944-1948); Bomba jugosłowiańska (1949-1955); Normalizacja (1956-1962); Ku decentralizacji i kulturom narodowym (1963-1973) itd.

Croatica daje w rezultacie obraz tytułowej ,literatury i kultury chorwackiej w Polsce w latach 1944-1989”, chociaż jest to zarazem i więcej, i mniej niż deklarowano. Oferuje więcej, gdyż prezentowany zakres jugosłowiański znacznie wykracza poza ramy deklarowanej perspektywy chorwackiej. To ogromna wartość publikacji, nadająca jej wielkie znaczenie, wagę, rangę. Jednocześnie tytułowa formulacja wydaje się zbyt szeroka, gdyż zwyczajowo bywa ona zarezerwowana dla opracowań o charakterze historycznoliterackim, syntez, w których dyskurs interpretacyjny narracji odautorskiej ma znaczenie kluczowe i dominujące. W omawianej pozycji uzyskujemy natomiast wgląd w sferę materii literackiej zawartej pomiędzy twórcą i jego dziełem, opublikowanym w języku pierwotnym, a przekładem. Dominuje obraz instytucjonalnego, społecznego, kulturowego charakteru współpracy międzyliterackiej. Najczęściej powtarzanym autorskim terminem jest „wymiana” i ,przekład”, przy czym autor wprowadza rozróżnienie pomiędzy współpracą, wymianą i kontaktami. Leszek Małczak posługuje się także terminem ,ogniwa pośredniczące”, wskazując na 
zakres swego naukowego zainteresowania. Repertuar badawczy obejmuje m.in. następujące kwestie: polityczne aspekty wymiany kulturalnej, politykę kulturalną z perspektywy chorwackiej i serbskiej, politykę przekładową i wydawniczą, działalność instytucji rządowych, dyplomatycznych i stowarzyszeń twórców w kontekście wymiany kulturalnej, charakterystykę zawartości problemowej, czasopism literackich i kulturalnych, ale pojawiają się też nowe terminy wskazujące na poszerzenie perspektywy badawczej o marketing i public relations (lokowanie książek, finansowanie współpracy kulturalnej, wymiana i współpraca prasowa). Kwestie rzeczywistej recepcji zajmują nieznaczny obszar zainteresowania badawczego, sprowadzając się do referencjalnej prezentacji i streszczeń opinii, recenzji i notatek prasowych. Oddajmy jednak sprawiedliwość autorowi, który zrealizował ogromne dzieło, zgodne z pierwotnym zamiarem. Dopiero Croatica otworzy innym opracowaniom drogę do hermeneutycznej, problemowej czy jakiejkolwiek innej interpretacji kwestii recepcyjnych, tak jak zwykle bywają one rozumiane w refleksji teoretyczno- i historycznoliterackiej.

Monumentalną monografię uzupełnia równie imponująca pod względem rozmiaru, zakresu i ambicji część pomocnicza, na którą składają się: bibliografia źródeł (s. 549-577), bibliografia przekładów książek (s. 579613), przekładów w czasopismach (s. 615-654), bibliografia tekstów o literaturze chorwackiej (s. 655-728), kalendarium chorwacko-polskich kontaktów kulturalnych w latach 1944-1989 (s. 729-794), spis ilustracji (s. 795-806), wykaz skrótów i skrótowców (s. 807-816), wykaz użytych nazw instytucji w tłumaczeniu na język polski (s. 817-822), indeks osobowy (s. 823-854), summary i sažetak. 